\title{
PENGEMBANGAN BUKU AJAR PERKEMBANGAN HEWAN BERBASIS HASIL PENELITIAN REGENERASI SIRIP KAUDAL IKAN GATUL (Poecilia sp.)
}

\author{
Nikmatul Iza ${ }^{1}$, Primadya Anantyarta ${ }^{2}$ \\ ${ }^{1,2}$ Program Studi Pendidikan Biologi, Fakultas Pendidikan Ilmu Eksakta dan Keo- \\ lahragaan IKIP Budi Utomo Malang. Jl. Citandui No.46 Malang \\ E-mail: nikmatuliza23.kendedes@gmail.com
}

\begin{abstract}
The development of textbooks aims to produce textbooks on animal development courses based on the results of research on regeneration of Gatul fish caudal fin (Poecilia sp.) As a model animal candidate in the field of developmental biology, which can later be used as a supporting book in the learning process of biology education students, IKIP Budi Utomo Malang. The method in developing this textbook uses the Hannafin \& Peck (1988) development model which consists of three phases, namely (1) the phase of needs analysis (need assessment), (2) the design (design) phase, and (3) the development and implementation phases (develop/implement). The steps taken include needs analysis, product design, product creation in the form of textbooks, and product validation. This development model is product-oriented. The instruments in this study were questionnaires and interviews, then the data were analyzed descriptively from the results of the validation of material experts, media experts, and individual tests (readability tests) on students on a large scale. The results of the validation of material experts showed a score of $96.66 \%$, validation of media experts had a score of $97.25 \%$, and individual validation (readability test) obtained a score of $94.48 \%$. Based on the results of the validation shows that both material experts, media experts and individual tests are very suitable to be used with very valid categories.
\end{abstract}

Keywords: textbook, animal development, regeneration of kaudal fins, Gatul fish

\begin{abstract}
Abstrak: Pengembangan buku ajar bertujuan untuk menghasilkan buku ajar matakuliah perkembangan hewan berbasis hasil penelitian regenerasi sirip kaudal ikan Gatul (Poecilia sp.) sebagai kandidat hewan model dibidang biologi perkembangan, yang nantinya dapat digunakan sebagai buku penunjang dalam proses pembelajaran mahasiswa pendidikan biologi, IKIP Budi Utomo Malang. Metode dalam pengembangan buku ajar ini menggunakan model pengembangan Hannafin Peck (1988) yang terdiri dari tiga fase yakni (1) fase analisis kebutuhan (need assessment), (2) fase desain (design), dan (3) fase pengembangan dan implementasi (develop/implement). Tahapan yang dilakukan meliputi analisis kebutuhan, perancangan produk, pembuatan produk berupa buku ajar, dan validasi produk. Model pengembangan ini berorientasi pada produk. Instrumen dalam penelitian ini berupa angket dan wawancara, selanjutnya data dianalisis sesara deskriptif dari hasil validasi ahli materi, ahli media, dan uji perorangan (uji keterbacaan) pada mahaiswa dalam skala besar. Hasil validasi ahli materi menunjukkan skor sebesar $96,66 \%$, validasi ahli media memiliki skor sebesar $97,25 \%$, dan validasi perorangan (uji keterbacaan) memperoleh skor sebesar $94,48 \%$. Berdasarkan hasil validasi menunjukkan bahwa baik ahli materi, ahli media maupun uji perorangan sangat layak digunakan dengan katagori sangat valid.
\end{abstract}

Kata kunci: buku ajar, perkembangan hewan, regenerasi sirip kaudal, ikan Gatul

Pembaharuan dalam kurikulum pendidikan tinggi menuntut dosen untuk menerapkan pembelajaran yang orientasinya pada mahasiswa (student centered) bukan berorientasi pada dosen (teacher centered), dalam hal ini dosen hanya bertidak sebagai fasilitator dalam proses pembelajaran. Pada awalnya sistem pembelajaran menekankan hanya pada penguasaan materi (aspek kognitif) saja tanpa memperhatikan kemampuan dalam ranah keterampilan proses (aspek psikomotorik) dan sikap/akhlaq (aspek afektif) yang sangat penting bagi lulusan sejalan dengan pasal 3 
UU no 20 yaitu menjadikan manusia yang beriman \& bertakwa kepada Tuhan Yang Maha Esa, berakhlak mulia, sehat, berilmu, cakap, kreatif, mandiri, dan menjadi warga negara yang demokratis serta bertanggung jawab. Pendidikan dalam hal ini tidak hanya sekedar membuat mahasiswa berpengetahuan, tapi juga dimaksudkan untuk mencetak karakter suatu sikap kedisiplinan ilmu yang menuju pada aspek IPTEK (ilmu pengetahuan dan teknologi), yakni mampu berfikir kritis, inovatif, logis, dan konsisten, serta mampu beradaptasi (Putro, dkk., 2016) terhadap kondisi apapun.

Perkembangan IPTEK juga harus dibarengi dengan perkembangan dibidang pendidikan, salah satu upaya yang dilakukan untuk memanfaatkan IPTEK adalah dengan mengimplementasikan hasil penelitian dalam proses pembelajaran melalui PBR (pembelajaran berbasis riset atau penelitian) yang merupakan bagian dari metode SCL (student center learning) (Putro, dkk., 2016). Pada pembelajaran berbasis riset (PBR) terdapat tiga tahap yaitu eksposure stage (mengetahuai kemampuan mahasiswa), eksperience stage (pemberian pengalaman dengan penelitian), dan capstone stage (menyuguhkan hasil riset secara tulisan dan lisan (Rohayati dkk., 2015 dalam Tangi, 2016).

Beberapa cara memadukan pembelajaran dan riset yaitu buku ajar dengan hasil penelitian dosen, menggunakan temuan penelitian termutakhir, kegiatan pembelajaran dengan isu-isu penelitian kontemporer; mengajarkan metodologi penelitian dalam proses pembelajaran, pembelajaran dengan kegiatan penelitian dalam skala kecil, mendorong mahasiswa agar merasa menjadi bagian dari budaya penelitian di program studi, memperkaya proses pembelajaran dengan nilai-nilai yang harus dimiliki oleh peneliti (Griffith Institute, 2008 dalam Subekti, 2016).

Hasil observasi melalui wawancara menunjukkan bahwa matakuliah struktur perkembangan hewan diajarkan pada mahasiswa semester II dan merupakan matakuliah wajib S1 pendidkan biologi, IKIP
Budi Utomo Malang. Dalam proses pembelajarannya tidak adanya buku ajar sebagai penunjang menjadikan mahasiswa terkendala untuk memahami konsep materi yang dipelajari terkhusus pada materi regenerasi yang secara faktual membutuhkan sumber belajar yang bersifat nyata. Hal ini dikarenakan pada materi tersebut selain materi juga diperlukan praktek dalam laboratorium untuk meningkatkan kinerja dan keterampilan mahasiswa. Oleh karena itu perlu menyajikan buku ajar yang kontennya tidak hanya membahas materi saja tapi juga dilengkapi dengan hasil-hasil penelitian yang relevan yang dilakukan oleh dosen/peneliti dengan teknik tentang proses regenerasi sebagai contoh yang kontekstual.

Berdasarkan latar belakang tersebut, maka penelitian ini bertujuan untuk menghasilkan buku ajar perkembangan hewan berbasis hasil penelitian sebagai sumber belajar atau buku penujang yang saat ini masih sangat minim sebagai pegangan baik untuk dosen maupun mahasiwa. Bahan ajar yang dikembangkan berupa buku teks yang konten isinya berupa kajian teori dan materi, teknik analisis, dan hasil penelitian regenerasi sirip kaudal ikan Gatul (Poecilia $s p$.) sebagai kandidat hewan model dibidang biologi perkembangan khususnya regenerasi yang harapannya dapat digunakan sebagai dasar atau acuan dalam mempelajari proses regenerasi berbagai jenis ikan di Indonesia.

\section{METODE}

Penelitian ini merupakan pengembangan bahan ajar dalam bentuk buku ajar. Pengembangan buku ajar ini menggunakan model pengembangan Hannafin dan Peck (1988) yaitu model desain pengajaran yang terdiri dari tiga fase, yaitu (1) fase analisis kebutuhan (need assessment), (2) fase design (design), dan (3) fase pengembangan dan implementasi (develop/implement). Model ini adalah model desain pembelajaran berorientasi pada produk (Kurniawan dkk., 2016; Megawati dkk., 2015; Prastomo \& Irawan, 2015; Putro, 2016). Gambar di bawah ini menunjukkan tiga fase utama dalam model Hannafin dan Peck (1988). 


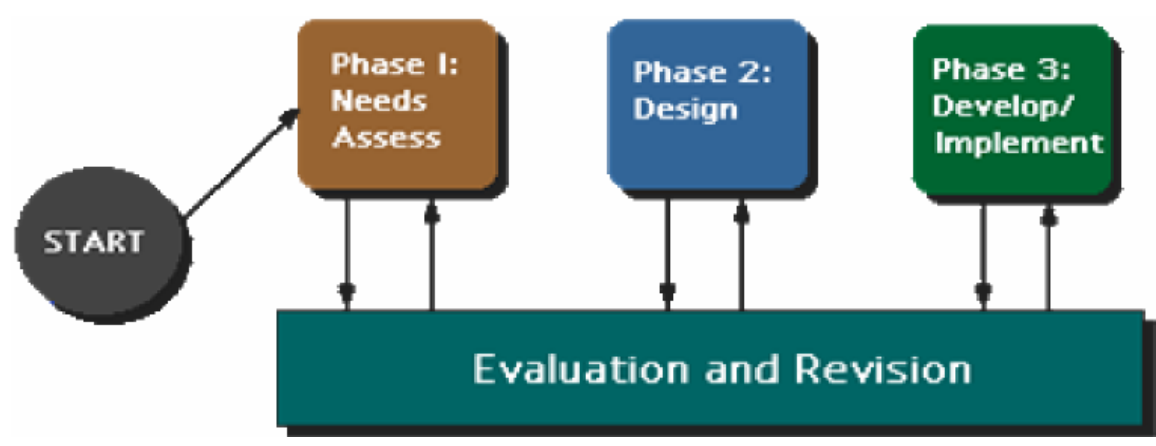

Gambar 1. Langkah-langkah Model Pembelajaran Hannafin dan Peck (1988) (Supriatna dan Mulyadi, 2009).

Prosedur penelitian dan pegembangan buku ajar Perkembangan hewan berbasis penelitian terdiri dari beberapa fase berikut ini.

\section{. Analisis}

Pada fase ini, peneliti mempelajari permasalahan yang akan dianalisis meliputi proses pembelajaran yang dilakukan mahasiswa Program Studi Pendidikan Biologi IKIP Budi Utomo Malang, sumber belajar, metode pembelajaran dengan cara melakukan wawancara dengan mahasiswa dan dosen pengampu mata kuliah perkembangan hewan.

\section{b. Desain dan Pengembangan}

Perancangan draft buku ajar berbasis hasil penelitian yang dilakukan pada fase desain direalisasikan pada fase pengembangan yang telah disesuaikan dengan analisis kebutuhan kondisi mahasiswa.

\section{c. Implementasi}

Fase implementasi merupakan fase uji coba produk. Uji coba dilakukan dengan maksud untuk mengetahui tingkat validasi/kelayakan dan daya tarik produk buku ajar yang dikembangkan. Tingkat validitas dan daya tarik produk dilihat dari beberapa tahap, yaitu tahap uji ahli materi perkembangan hewan untuk menilai isi atau materi bahan ajar, uji ahli media pembelajaran untuk melihat pengembangan bahan ajar, dan uji coba perorangan dengan skala besar untuk menilai keterbacaan dan daya tarik buku.

Validasi ahli materi dilakukan dosen pengampu matakuliah perkembangan hewan di Program Studi Pendidikan Biologi IKIP
Budi Utomo Malang. Validasi uji ahli media dilakukan bagi dosen yang memiliki bidang keahlian media pembelajaran dan pengembangan bahan ajar yaitu dosen Universitas Negeri Malang dan IKIP budi Utomo Malang, dan uji keterbacaan dan daya tarik buku ditujukan kepada mahasiswa Program Studi Pendidikan Biologi yang telah menempuh matakuliah perkembangan hewan. Analisis deskriptif dengan pendekatan kualitatif digunakan untuk mengolah data dari penilaian para ahli. Teknik analisis data ini digunakan dengan mengumpulkan informasi dari data kualitatif yang berupa kemenarikan, kelayakan, kelebihan buku ajar serta saran perbaikan dari validasi ahli materi, validasi ahli media, dan uji perorangan.

Analisis skor yang terhimpun dari lembar hasil validasi para ahli dimaksudkan untuk mendapatkan gambaran yang jelas tentang bahan ajar yang dikembangkan. Data yang terhimpun tersebut, kemudian dihitung persentase dari setiap butir pertanyaan pada lembar validasi tersebut dengan rumus sebagai berikut:

$$
\mathrm{K}=\frac{\mathrm{F}}{\mathrm{N} \times \mathrm{I} \times \mathrm{R}} \times 100 \%
$$

Keterangan

K : Persentase Kelayakan

F : Jumlah Jawaban Responden

N : Skor Tertinggi dalam Angket

I : Jumah Pertanyaan dalam Angket

R : Jumlah Responden

(Riduwan, 2003). 
Iza \& Anantyarta, Pengembangan Buku Ajar...

Penafsiran dan kesimpulan hasil ketentuan yang terdapat pada Tabel 1 sesuai dengan kriteria penilaian ideal dengan berikut:

Tabel 1. Kriteria Persentase Respon Validator

\begin{tabular}{cll}
\hline Skor & \multicolumn{1}{c}{ Keterangan } & \multicolumn{1}{c}{ Keputusan Uji } \\
\hline $0 \%-20 \%$ & Sangat Kurang Valid & Tidak layak dan perlu revisi besar \\
$21 \%-40 \%$ & Kurang Valid & Kurang layak dan perlu revisi besar \\
$41 \%-60 \%$ & Cukup Valid & Cukup layak dan perlu revisis besar \\
$61 \%-80 \%$ & Valid & Layak namun tetap dilakukan revisi kecil \\
$81 \%-100 \%$ & Sangat Valid & $\begin{array}{l}\text { Sangat layak dan tidak perlu revisi jka } \\
\text { mencapai 100\% }\end{array}$ \\
& & \\
\hline
\end{tabular}

(Riduwan, 2003).

\section{HASIL}

Hasil penelitian dapat dijabarkan sesuai metode pengembangan pada buku ajar antara lain:

1. Need Assasment

Pada tahap analisis kebutuhan diperoleh temuan bahwa sumber belajar yang digunakan mahasiswa sebagian besar menggunakan jurnal berbahasa inggris, sehingga akan mempengaruhi pemahaman konsep mahasiswa, selain itu belum adanya buku yang secara spesifik menjelaskan tentang materi regenerasi. Metode pembelajaran yang digunakan masih kuno yang mengandalkan metode ceramah, pembuatan makalah dan presentasi kelompok, membuat resume, serta kegiatan praktikum masih sangat minim dilakukan, sehingga secara tidak langsung keterampilan kerja ilmiah siswa masih sangat kurang. Mahasiswa mengharapkan sumber belajar yang dibuat sendiri oleh dosen pengampu berdasarkan hasil penelitian yang dilakukan dosen sendiri, sehingga tampak lebih riil dan kontekstual, ddilengkapi dengan gambar yang sesuai dan menarik pembaca, dengan menggunakan bahasa indonesia yang mudah di pahami yang sesuai dengan karakteristik mahasiswa IKIP Budi Utomo Malang yang terdiri dari berbagai etnis atau suku bangsa

\section{Desain and Develop}

Pada tahap ini perancangan buku ajar (fase desain) direalisasikan pada (fase pengembangan). Pada produk buku ajar menyajikan bagian kulit muka (sampul/cover depan) dan bagian kulit belakang (sampul/cover belakang), sampul dalam, kata pengantar, daftar isi, daftar gambar, daftar tabel, BAB I sampai dengan BAB IV yang memuat pokok bahasan, tujuan pembelajaran, ketercapaian, dan dilengkapi dengan soal latihan pada tiap BAB, serta pemahaman yang diperoleh mahasiswa setelah mempelajari buku ajar berbasis hasil penelitian. Buku ajar ini juga dilengkapi dengan daftar rujukan yang kebanyakn berasal dari jurnal internasional, karena masih belum adanya buku yang mempelajari tentang regenerasi pada ikan, khususnya ikan Gatul.

\section{Implement}

Pada fase implementasi merupakan tahap dalam uji produk. Pertama yaitu validasi materi oleh dosen pengampu matakuliah perkembangan hewan yang berkompeten pada bidang regenerasi. Penilaian ahli materi meliputi penilain pada $\mathrm{BAB}$ I sampai $\mathrm{BAB}$ IV. BAB I (Pendahuluan) memaparkan tentang regenerasi secara umum dan pembagiannya berdasarkan mekanisme seluler, serta proses regenerasi sirip kaudal ikan Zebra (Danio rerio) yang telah digunakan sebagai hewan model dibidang regenerasi yang memuat teori dan praktik. BAB II membahas tentang Ikan Gatul (Poecilia sp.) dengan pokok bahasa taksonomi dan morfologi Ikan Gatul secara umum berdasarkan hasil pengamatan dan studi literatur. BAB III menyajikan teknik analisis regenerasi sirip kaudal pada ikan yang mencakup tata tertib praktikum, pendahuluan, tujuan yang diharapkan setelah praktikum, dasar teori, rancangan percobaan 
regenerasi sirip kaudal, alat dan bahan yang dibutuhkan dan menunjang kegiatan praktikum, metode pengukuran sirip kaudal ikan, proses pemotongan sirip kaudal ikan, teknik pengumpulan data, teknik analisis data, dan contoh skema teknik analisis. BAB IV menyuguhkan hasil regenerasi sirip kaudal ikan Gatul yang menjelaskan tentang proses regenerasi sirip kaudal ikan Gatul, proses regenerasi sirip kaudal ikan Gatul yang mengalami malformasi akibat kerusakan mekanis, durasi dan jenis regenerasi yang harapannya dapat dijasikan sebagai kandidat hewan model dibidang biologi perkembangan khususnya regenerasi. Penyajian data hasil validasi ahli materi tertuang dalam Tabel 2.

\section{Tabel 2. Data Hasil Validasi Buku Ajar Berbasis Hasil Penelitian oleh Ahli Materi}

\begin{tabular}{llcc}
\hline No & \multicolumn{1}{c}{ Aspek Penilaian } & $\begin{array}{c}\text { Skor Rata-rata } \\
(\mathbf{\%})\end{array}$ & Kualifikasi \\
\hline 1 & Regenerasi & 94,99 & Sangat Valid \\
2 & Ikan Gatul (Poecilia sp.) & 96,99 & Sangat Valid \\
3 & $\begin{array}{l}\text { Teknik Analisis Regenerasi } \\
\text { Sirip Kaudal Ikan }\end{array}$ & 96,99 & Sangat Valid \\
4 & $\begin{array}{l}\text { Hasil Regenerasis Sirip } \\
\text { Kaudal Ikan Gatul (Poecilia } \\
\text { sp.) }\end{array}$ & 98,33 & Sangat Valid \\
\hline \multicolumn{2}{c}{ Rata-rata Skor } & $\mathbf{9 6 , 6 6}$ & Sangat Valid \\
\hline & & & Komponen \\
\hline
\end{tabular}

Ahli Materi

\section{Kemenarikan:}

1. Memberikan pemahaman yang kontekstual, disertai kegiatan praktikum langsung di laboratorium.

2. Memberikan khasanah baru tentang hewan model yang layak digunakan pengamatan bagi mahasiswa.

\section{Kelayakan}

1. Sangat layak digunakan karena memudahkan dosen dan mahasiswa dalam proses pembelajaran baik teori maupun praktek.

2. Secara umum materi sangat sesuai dan sejalan dengan soal latihan yang diberikan dan isi materi mudah dipahami.

\section{Kelebihan}

1. Memberikan contoh yang riil berdasarkan hasil penelitian.

2. Bahasa sederhana dan mudah dipahami, isi materi sangat cocok dengan karakter mahasiswa IKIP Budi Utomo Malang, dan pemilihan gambar yang tepat.

\section{Saran}

1. Saran pada tabel istilah asing sebaiknya ditambahkan keterangan bahasa Indonesia.

2. Diperbaiki beberapa kalimat yang sedikit ambigu.

Tabel 2 menunjukkan bahwa pada BAB I dengan topik regenerasi dengan aspek penilain topik dikemukakan dengan jelas, kesesuaian materi pembelajaran dengan tujuan, kelengkapan komponen isi materi, kebenaran konsep materi pada buku 
ajar, kesesuaian antara soal latihan dengan topik, dan kelayakan soal sebagai alat ukur untuk mengukur kemampuan mahasiswa dalam memahami isi materi yang disajikan memperoleh skor sebesar 94, 99\%, BAB II dan BAB III mendapatkan skor sebesar 96,99\% dan BAB IV memperoleh skor sebesar 98,33\% dengan rata-rata skor ahli materi sebesar 96,99\% dengan katagori sangat valid.

Fase kedua yaitu validasi media oleh dosen yang berkompeten dalam bidang media pembelajaran dan pengembangan bahan ajar yang tampak pada Tabel 3 .

Tabel 3. Data Hasil Validasi Buku Ajar Berbasis Hasil Penelitian oleh Ahli Media.

\begin{tabular}{|c|c|c|}
\hline No & Aspek Penilaian & $\begin{array}{c}\text { Skor Rata-rata } \\
(\%)\end{array}$ \\
\hline 1 & Desain Cover/Sampul Buku & Sangat Valid \\
\hline 2 & Tipografi Cover/Sampul Buku & Sangat Valid \\
\hline 3 & Desain Isi Buku & Sangat Valid \\
\hline 4 & Tipografi Isi Buku & Sangat Valid \\
\hline 5 & Kaidah Penulisan & 100 \\
\hline 6 & Kelayakan Penyajian & Sangat Valid \\
\hline & Rata-rata Skor & Sangat Valid \\
\hline & Validator & Komponen \\
\hline & Ahli Media & $\begin{array}{l}\text { Kemenarikan: } \\
\text { 1. Menarik untuk dibaca, dan dilengkapi dengan } \\
\text { prosedur yang jelas. } \\
\text { 2. Menyajikan berbagai gambar yang mampu mem- } \\
\text { buat pembaca memahami isi buku. } \\
\text { Kelayakan } \\
\text { 1. Sangat layak digunakan dalam kelas, namum di- } \\
\text { perlukan perbaikan sesuai dengan saran. } \\
\text { Kelebihan } \\
\text { 1. Buku ajar sudah dilengkapi dengan langkah dan } \\
\text { kegiatan praktikum yang dapat dilakukan oleh } \\
\text { mahasiswa dalam mengembangkan penelitian } \\
\text { lebih lanjut. } \\
\text { 2. Cover menarik, gambar jelas, prosedur penelitian } \\
\text { jelas, dan buku dikembangkan berdasarkan hasil } \\
\text { penelitian. } \\
\text { Saran } \\
\text { 1. Header dan footer, serta pemisahan antar bab } \\
\text { dibuat lebih berwarna lagi }\end{array}$ \\
\hline
\end{tabular}

Pada Tabel 3 menjelaskan bahwa hasil penilain yang didapatkan dari validator ahli media dengan aspek penilaian desain cover atau sampul buku dengan komponen kesesuaian ukuran buku dengan standart buku ajar (komposisi dan ukuran unsur tata letak judul, pengarang, dan illustrasi cover buku ajar bersifat proporsional), kemenarikan cover (gambar dan warna yang ditampilkan menarik), gambar yang digunakan sesuai dengan tema dan jelas, kesesuaian judul dengan isi buku ajar, serta identitas pada cover cukup jelas memperoleh skor sebesar $96 \%$. Tipografi cover/sampul buku dengan indikator ukuran huruf judul buku lebih dominan dan proporsional dibanding dengan ukuran buku dan nama pengarang, warna judul buku kontras/senada dengan warna latar belakang buku dengan skor sebesar $90 \%$. Desain isi buku dengan komponen pemisahan antar paragraf jelas, spasi antar teks sudah sesuai, judul bab, 
subbab, dang angka halama jelas, illustrasi dan keterangan gambar jelas memperoleh skor sebesar 97,5\%. Tipografi isi buku dengan indikator tidak menggunakan terlalu banyak jenis huruf, jenis huruf yang digunakan jelas mendapatkan skor $100 \%$, kaidah penulisan dengan komponen tampilan buku menarik, penggunaan bahasa indonesia yang baik dan benar serta komunikatif, struktur buku sistematis, kesesuaian tanda baca, dan etika penulisan sesuai dengan skor $100 \%$. Kriteria kelayakan penyajian dengan indikator kata pengantar menggambarkan isi buku ajar, daftar isi, daftar tabel, dan daftar gambar sesuai dengan yang ada pada buku ajar, pokok bahasan dan tujuan saling terkait, isi buku ajar dilengkapi dengan gambar yang menarik dan sesuai, serta bagian belakang dilengkapi dengan daftar rujukan mendapat skor sebesar $100 \%$ dengan rata-rata skor penilaian hali media yaitu $97,25 \%$ dengan katagori sangat layak.

Tahap uji coba perorangan untuk melihat keterbacaan buku dilakukan setelah memperoleh masukan dan saran dari ahli materi dan media. Subjek pada tahap ini adalah mahasiswa pendidikan biologi sejumlah 80 orang dengan skala besar yang telah menempuh matakuliah struktur perkembangan hewan. Adapun hasil dari uji perorangan dapat dilihat pada tabel 4

Tabel 4. Data Hasil Validasi Uji Perorangan

\begin{tabular}{cccc}
\hline No & Aspek Penilaian & Skor Rata-rata (\%) & Kualifikasi \\
\hline 1 & Kemudahan Materi & 94,35 & Sangat Valid \\
2 & Kemenarikan Buku & 94,06 & Sangat Valid \\
3 & Keterpahaman Materi & 94,51 & Sangat Valid \\
4 & Keterbaharuan Materi & 95,02 & Sangat Valid \\
\hline \multicolumn{2}{c}{ Rata-rata Skor } & $\mathbf{9 4 , 4 8}$ & Sangat Valid \\
\hline \multicolumn{2}{c}{ Validator } & & Komponen \\
\hline
\end{tabular}

1. Materi yang disajikan sangat menarik, dengan gambar yang jelas dengan kualitas yang bagus, materi mudah dipahami, dan desain cover sangat bagus.

2. Materi dan gambar diambil dari penelitian langsung sehingga mudah dipahami dan mudah mempraktekkannya.

3. Uraian gambar menarik.

4. Dapat membantu pembaca karena sebelumnya belum terdapat buku khususnya regenerasi ikan Gatul.

\section{Kelayakan}

1. Sudah layak digunakan semua kalangan baik dosen maupun mahasiswa karena didalam buku ajar menyajikan hasil-hasil penelitian relevan dan mudah dipahami.

2. Layak digunakan baik dalam teori maupun praktek.

\section{Kelebihan}

1. Pada setiap bab terdapat tujuan pembelajaran disertai dengan latihan soal.

2. Terdapat gambar-gambar yang menarik dan bahasa yang digunakan mudah dipahami.

3. Materi yang disajikan padat dan jelas.

4. Dapat digunakan sebagai sumber belajar baik didalam teori maupun praktek. 


\section{Saran \\ 1. Warna cover disarankan disesuaikan dengan habitat ikan. \\ 2. Pada hal (i) penulisan buku ajar berbasis hasil penelitian dibuat lebih menarik lagi.}

Pada tabel 4 menunjukkan bahwa hasil validasi kelompok perorangan untuk melihat keterbacaan dan daya tarik buku dengan kriteri kemudahan materi dengan indikator bahasa yang digunakan yaitu bahasa indonesia dengan baik dan benar dan kumikatif, kesesuaian penggunaan tanda baca, dan materi yang mudah dipahami dengan skor sebesar 94,35\%. Pada aspek kemenarikan buku dengan komponen materi yang disajikan menarik serta sesuai dengan judul pokok bahasan, media gambar tampilannya menarik dan jelas, dan terdapat uraian gambar yang jelas dan mudah dipahami mendapatkan skor sebesar 94,06\%.

Pada kriteria keterpahaman materi dengan cakupan adanya keterkaitan antara konsep dengan tujuan pembelajaran, keterpaduan antar bab, serta konsep materi yang mudah dipahami pada buku ajar memiliki skor sebesar 94,51\%. Pada aspek keterbaharuan materi dengan indikator pemahaman konsep (materi dilengkapi dengan hasil penelitian), materi dilengkapi dengan teknik analisis, dan materi yang digunakan kebanyakn berasal dari jurnal memperoleh skor sebesar 95,02. Adapun skor rata-rata uji perorangan sebesar $94,48 \%$ dengan katagori sangat valid.

\section{PEMBAHASAN}

Buku ajar perkembangan hewan berbasis hasil penelitian dikembangkan merujuk model pengembangan Hannafin Peck (1988). Produk awal pengembangan buku ajar divalidasi oleh tim ahli materi dan ahli media, serta diuji keterbacaan oleh mahasiswa S1. Hasil yang diperoleh dari validasi dan respon mahasiswa sangat antusias dan menarik perhatian, serta mendapatkan tanggapan yang baik (positif). Apalagi buku ajar yang dikembangkan diperoleh dari hasil penelitian yang tentunya dapat mendorong dosen untuk melakukan penelitian atau mengupdate keilmuannya, peran mahaiswa menjadi lebih dominan dan aktif dalam pembelajaran, kemungkinan menjadi bagian dalam penelitian dosen, menjadikan mahasiswa lebih mandiri, kreatif, dan kristis yang akan memunculkan peluang berupa ide, gagasan, dan inovasi baru, serta melatih mahasiswa dalam etika profesi yaitu plagiarism (Widayati dkk., 2010), sehingga hasil penelitian yang dilakukan bersifat faktual dan terpercaya.

Proses validasi merupakan bagian dari proses evaluasi yang dimaksudkan untuk melihat buku ajar tersebut sudah baik (layak) atau mungkin masih ada sesuatu yang perlu diperbaiki (Depdiknas, 2008 dalam Fadilah dkk., 2016). Penilaian oleh ahli materi sangat penting dilakukan sesuai dengan bidang dan keahlian masing-masing, sehingga saran maupun masukan yang diberikan dapat membangun dan menyempurnakan buku ajar yang dikembangkan menjadi semakin baik, perfect, valid, dan layak untuk digunakan. Menurut Depari dkk., 2016 pengembangan buku ajar merupakan salah satu bentuk dari proses pembelajaran yang sifatnya memperbaiki atau meningkatkan proses pembelajaran. Buku ini dijadikan sebagai buku teks pelengkap yang dapat membantu melengkapi buku teks utama yang digunakan oleh dosen dan mahasiswa (Prastowo, 2005).

Buku ajar yang dihasilkan memuat tentang hasil penelitian regenerasi sirip kaudal ikan, khususnya ikan Gatul Poecilia sp.) yang masih minim pemanfaatannya khususnya terkait regenerasi sirip kaudal. Pemilihan ikan Gatul juga dikarenakan memiliki kemampuan berkembang biak dengan cepat yang menjadikan populasinya berkembang dengan pesat (cepat) (Iza dkk., 2016). Kedepannya diharapkan hasil 
penelitian ini dijadikan dasar dalam pemilihan ikan Gatul sebagai cikal bakal/kandidat ikan model regenerasi.

\section{KESIMPULAN DAN SARAN}

\section{Kesimpulan}

Pengembangan buku ajar berbasis hasil penelitian yang telah disusun memiliki hasil validasi sangat valid baik dari ahli materi, ahli media, maupun uji perorangan oleh mahasiswa pendidikan biologi, sehingga sangat layak digunakan dalam proses pembelajaran matakuliah struktur perkembangan hewan.

\section{Saran}

Dalam penggunaan buku ajar ini, terdapat beberapa saran yaitu (1) penggunaan buku ajar berbasis hasil penelitian ini sebaiknya bersamaan dengan buku teks yang lain (jika ada), sehingga dapat saling menunjang dan melengkapi. (2) perlu adanya pengujian lebih lanjut tentang proses regenerasi sirip kaudal ikan Gatul dengan pemotongan berbagai pola dan perlu kajian lebih lanjut pada tingkat molekuler, sehingga dapat diketahui gen yang mengekspresikan dalam proses regenerasi.

\section{DAFTAR RUJUKAN}

Depari, T. V. B. 2016. Pengembangan Buku Ajar Biologi Topik Ekologi Kelas VII SMP Berbasi Penemuan Terbimbing dengan emanfaatkan Lingkungan Kebun Sayur. Jurnal Pendidikan IndonesiaI. 6 (1): 233-241.

Fadilah, R. E.., Amin, M., Lestari, U. 2016. Pengembangan Buku Ajar Evolusi Berbasis Penelitian untuk Mahasiswa S1 Pendidikan Biologi Universitas Negeri Jember. Jurnal Pendidikan: 1(6): 1104-1109.

Iza, N., Listyorini, D., Gofur, A. 2016. Regenerasi Sirip Kaudal Ikan Gatul yang Mengalami Malformasi. Edubiotik. 1(1): 42-47

Kurniawan, K. U., Parmiti, D. P., Tastra, \& I. D. K. 2016. Pengembangan Multimedia Ular Tangga Model Hannaf- in dan Peck untuk Meningkatkan Hasil Belajarmata Pelajaran IPA pada Siswa Kelas VIII Semester Genap Di SMP Negeri 6 Singaraja Tahun Pelajaran 2015/2016. e-Journal Edutech Universitas Pendidikan Ganesha 5:2

Megawati, N. L. P., Agung, A. A. G., Suartama, I. K. 2015. Pengembangan Video Pembelajaran Ipa Model Hannafin dan Peck untuk Siswa Kelas VII SMP Negeri 1 Sawan. $e$ Journal Edutech Universitas Pendidikan Ganesha Jurusan Teknologi Pendidikan: 3(1).

Prastomo, A \& Irawan, A. 2015. Pengembangan Media Pembelajaran Interaktif Berbasis Web Menggunakan Metode Hannafin dan Peck. Jurnal Positif 1(1): 14-28

Prastowo, A. 2015. Panduan Kreatif Membuat Bahan Ajar Inovatif (Menciptakan Metode Pembelajaran yang Menarik dan Menyenangkan). Diva Press: Jogjakarta.

Putro, S. D. K., Lestari, U., Lukiati, B. 2016. Pengembangan Buku Ajar Perkembangan Hewan Berbasis Penelitian Metamorfosis Ulat Sutera Bombyx mori L. Jurnal Pendidikan: Teori, Penelitian, dan Pengembangan. 1(7): 1229-1234.

Riduwan. 2003. Dasar-Dasar Statistika. Bandung: Alfabeta.

Subekti, H. 2016. Representasi penggunaan media digital dan pembelajaran berbasis Penelitian: sebuah survei untuk mengukur perilaku pada Mahasiswa baru di program studi pendidikan sains unesa. Jurnal Penelitan Pendidikan IPA. 1(1):7-12

Supriatna, D dan Mulyadi, M. 2009. Konsep Dasar Desain Pembelajaran. Jakarta: Pusat Pengembangan dan Pemberdayaan Pendidik dan Tenaga Kependidikan

Tangi, H. 2016. Pengaruh Model Pembelajaran Berbasis Riset 
Iza \& Anantyarta, Pengembangan Buku Ajar...

terhadap Hasil Belajar Mahasiswa Kimia. Jipera. 1(1): 2503-2534.

Widayati, D. T., Luknanto, D., Rahayuningsih, E., Sutapa, G., Harsono., Sancayaningsih, R. P., \& Sajarwo. 2010. Pedoman Umum Pembelajran berbasis Riset (PUPBR). Universitas Gadjah Mada. 